\title{
ANALISIS PELATIHAN TERHADAP PENGEMBANGAN KARYAWAN PADA PT SURYA TOTO INDONESIA
}

\author{
Pusporini Palupi Jamaludin ${ }^{1^{*}}$ \\ ${ }^{1)}$ Universitas Pamulang \\ *Penulis Korespondensi: dosen01399@unpam.ac.id
}

\begin{abstract}
Penelitian ini bertujuan untuk mengetahui Pelatihan dan Pengembangan Karyawan di PT Surya Toto Indonesia Unit Serpong Bagian Warehouse, dan juga untuk mengetahui analisis pelatihan karyawan terhadap Pengambangan karyawan karyawan PT Surya Toto Indonesia Unit Serpong Bagian Warehouse. Metode penelitian yang digunakan dalam penelitian ini menggunakan metode pendekatan kualitatif, dengan model penelitian yaitu fenomenologi. Sumber data yang digunakan adalah sumber data primer dan sekunder dan teknik sampling yang digunakan dalam penelitian ini adalah teknik purposive samping Dalam penelitian kualitatif peneliti memiliki subyek penelitiannya tidak lebih dari sepuluh sampel. Adapun ciri khas dari wawancara mendalam ini didasarkan oleh sampel yang totalnya sebanyak sepuluh orang. Hal ini ditunjukkan jumlah informan utama sebanyak tujuh orang dan trigulasi sebanyak tiga orang. Metode pengumpulan data menggunakan sumber primer dan sekunder, teknik pengumpulan data dengan cara observasi, wawancara, studi dokumentasi dan gabungan atau triangulasi. Dari penelitian yang dilakukan dan hasil yang diperoleh maka dapat disimpulkan : Hasil observasi peneliti dan hasil wawancara bersama para karyawan yang peneliti jadikan informan utama dan para pimpinan yang dijadikan sebagai trigulasi yaitu Pelatihan bagi perusahaan merupakan aktivitas yang penting dilakukan, di mana hal ini akan dapat mempengaruhi tingkat hasil kinerja dan prestasi kerja bagi tenaga kerja itu sendiri dan organisasi atau perusahaan di mana tenaga kerja tersebut bekerja.
\end{abstract}

Keywords: Pelatihan Karyawan, Pengembangan Karyawan 


\section{PENDAHULUAN}

Peran perusahaan juga penting dalam proses memberikan pelatihan atau pendidikan terhadap karyawan agar lebih berkualitas dan memiliki integritas tinggi demi memberikan kepuasan pelanggan, mengembangkan pelayanan melalui pengetahuan dan pemanfaatan teknologi, menjalankan tata kelola perusahaan yang baik guna meningkatkan nilai tambah bagi pemangku kepentingan, dan menciptakan lingkungan kerja terbaik bagi karyawan untuk berkarya dan berprestasi.

Pelatihan adalah usaha mengurangi atau menghilangkan terjadinya kesenjangan antara kemampuan karyawan dengan yang dikehendaaki organisasi. Usaha tersebut dilakukan melalui peningkatan kemampuan kerja yang dimiliki karyawan dengan cara menambah pengetahuan dan keterampilan serta mengubah sikap. Selain untuk meningkatkan kinerja, pelatihan merupakan upaya untuk mengembangka sumber daya manusia, antara lain penambahan wawasan, intelektualitas, karakter, dan mental. Pelatihan karyawan merupakan bentuk investasi perusahaan yang tidak hanya membawa keuntungan yang tinggi, namun juga memiliki dampak positif terhadap kinerja perusahaan.

Dalam pelatihan karyawan materi pelatihan perlu di perhatikan, karena harus sesuai dengan peserta pelatihan dan juga tujuan dari pelatihan itu sendiri. Sebagai contoh ada beberapa karyawan yang memiliki kedisiplinan rendah yang tidak sesuai dengan aturan perusahaan, maka karyawan tersebut masuk dalam kategori peserta untuk diberikan pelatihan. Disamping itu Instruktur pelatihan juga harus bisa menguasai materi yang akan dibahas, sehingga dapat menggunakan metode pelatihan yang dapat dipahami oleh peserta pelatihan.

Tetapi fenomena yang terjadi Sebagai contoh ada beberapa karyawan yang merasa belum optimal terkait pelatihan yang diberikan dirasa membosankan, instruktur pelatihan yang dirasa kurang variatif dalam memberi materi pelatihan, Disamping itu Instruktur pelatihan juga harus bisa menguasai materi yang akan dibahas, sehingga dapat menggunakan metode pelatihan yang dapat dipahami oleh peserta pelatihan. Program pelatihan Persoalan yang timbul dalam pelatihan dan pengembangan yang dilakukan oleh perusahaan seringkali belum sesuai dengan kebutuhan perusahaan, tugas, dan individu sehingga tidak mendukung prestasi kerja dan karir karyawan, Hambatan yang terjadi saat melakukan pelatihan dan pengembangan yang diberikan belum maksimal, Hal ini dapat dilihat dari karyawan mengalami kesulitan dalam memahami materi pelatihan dan pengembangan yang diberikan.

Efektivitas pelatihan

karyawan merupakan hal yang sangat penting terutama untuk mengembangkan sumber daya manusia. Pelatihan dan pengembangan sumber daya manusia di perusahaan, organisasi, instansi pendidikan, ataupun lembaga lain dilakukan untuk meningkatkan kinerja karyawan. diadakan secara rutin untuk meningkatkan kualitas dari SDM Perusahaan.

\section{TINJAUAN PUSTAKA}

Menurut Sri Rahmi (2014: 19) kepemimpinan merupakan suatu kemampuan seseorang pemimpin untuk mempengaruhi, memotivasi, dan memungkinkan orang lain untuk berkontribusi terhadap efektivitas dan keberhasilan organisasi. Artinya sisi keefektifan sumberdaya organisasi dalam mencapai tujuan organisasi yang perlu dicapai secara efektif, jadi dapat dikatakan kepemimpinan yang efektif ialah yang dapat mempengaruhi orang lain sehingga mereka termotivasi untuk memberikan kontribusi pada pencapaian kelompok.

Menurut Hasibuan (2011: 43) Kepemimpinan adalah seseorang dengan wewenang kepemimpinannya mengarahkan bawahannya untuk mengerjakan sebagian dari pekerjaannya dalam mencapai tujuan. Jadi pemimpin harus mempunyai bawahan, harus membagi pekerjaannya dan harus tetap bertanggung jawab terhadap pekerjaan tersebut. Menurut Robert Tanembaum (2011: 43) Kepemimpinan adalah mereka yang menggunakan wewenang untuk mengorganisasi, mengarahkan, mengontrol para bawahan yang bertanggung jawab, supaya semua bagian pekerjaan dikoordinasi demi pencapaian tujuan perusahaan.

Dalam organisasi kinerja adalah jawaban dari berhasilnya atau tidaknya tujuan organisasi yang telah ditetapkan. Pemimpin perusahaan atau manajer seringkali 
mengabaikan dan tidak memperhatikan masalah kinerja kecuali kalau sudah amat buruk, terlalu sering tidak mengetahui betapa buruknya kinerja telah merosot sehingga perusahaan atau instansi menghadapi krisis yang serius.

Kinerja harus dilakukan dengan efektif dan efisien yang artinya dalam melaksanakan pekerjaan organisasi dengan menggunakan sumberdaya organisasi itu harus dilakukan dengan cermat dan teliti agar tidak terjadi pemborosn. Kinerja yang baik dan berkualitas bisa berakhibat baik juga bukan hanya dari perusahaan atau instansi tersebut tetapi bagi karyawan atau pegawi dari perusahaan itu sendiri, bahkan dapat dirasakan oleh masyarakat luas.

Menurut M. Ma'ruf (2014: 3) Kinerja adalah prestasi kerja yang merupakan hasil dari implementasi rencana kerja yang dibuat suatu istitusi yang dilaksanakan oleh pimpinan dan karyawan atau karyawan (SDM) yang bekerja diintitusi itu baik pemerintah maupun perusahaan bisnis untuk mencapaai tujuan organisasi.

Menurut Simanjuntak (2011: 1) Kinerja adalah tingkat pencapaian hasil atas pelaksanaan tugas tertentu. Sedangkan kinerja perusahaan adalah tingkat pencapaian hasil dalam rangka mewujudkan tujuan perusahaan.

Menurut Moeheriono dalam Abdullah (2014:

3) Kinerja atau performance merupakan gambaran mengenai tingkat pencapaian pelaksanaan suatu program kegiatan atau kebijakan dalam mewujudkan sasaran, tujuan, visi dan misi organisasi yang dituangkan melalui perencanaan strategis atau suatu organisasi.

Dari berbagai pengertian tentang kinerja diatas dapat disimpukan bahwa kinerja adalah merupakan pencapaian hasil kerja dari implementasi kerja yang dibuat oleh suatu institusi dalam mewujudkan sasaran, tujuan, visi dan misi organisasi yang dituangkan melalui perencanaan strategis suatu organisasi.

Terdapat Pedoman Aperatur Negara, Pedoman tersebut merupakan pedoman dalam melaksanakan kinerja kerja aparatur negara pada lingkungan instansi atau lembaga masingmasing, untuk menumbuhkan dan meningkatkan semangat kerja, kepemimpinan dan tanggung jawab moral aparaturnya secara terus-menerus dan konsisten, sesuai dengan tugas dan fungsi masing-masing. Menurut
Wirawan (2009: 5), kinerja adalah keluaran yang dihasilkan oleh fungsi-fungsi atau indikator-indikator suatu pekerjaan atau suatu profesi dalam waktu tertentu.

Menurut Irham Fahmi (2013: 2), kinerja adalah hasil yang diperoleh suatu organisasi baik organisasi tersebut bersifat profit oriented dan non profit oriented yang dihasilkan selama satu periode tertentu. Definisi dari kinerja merupakan suatu hasil kerja yang dihasilkan oleh seorang karyawan dalam melaksanakan tanggung jawabnya di dalam suatu organisasi yang dilakukan dalam suatu periode tertentu.

Pentingnya kinerja karyawan Dinas Pemadam Kebakaran Dan Penyelamatan adalah proses yang digunakan untuk memberikan manfaat pekerjaan yang baik jika dikerjakan dengan benar, dan mengukur sejauh mana kinerja karyawan Dinas Pemadam Kebakaran Dan Penyelamatan, hal ini memberikan manfaat yang penting bagi para karyawan maupun pimpinan dalam suatu organisasi, dan hasil evaluasi kinerja dapat dilakukan untuk menentukan tindakan yang tepat. Dan pentingnya kinerja karyawan perlu dicermati untuk mengetahui kemampuan karyawan, penerimaan tujuan karyawan, tingkat tujuan yang dicapai, dan interaksi antara tujuan dan kemampuan para karyawan dalam perusahaan dimana masing-masing elemen tersebut berpengaruh terhadap kinerja seseorang.

\section{METODE PENELITIAN}

Jenis penelitian ini adalah kualitatif penelitian kualitatif mengkaji perspektif partisipan dengan strategi-strategi yang bersifat interaktif dan fleksibel. Penelitian kualitatif ditujukan untuk memahami fenomenafenomena sosial dari sudut pandang partisipan. Penelitian kualitatif adalah penelitian yang digunakan untuk meneliti pada kondisi objek alamiah dimana peneliti merupakan instrumen kunci. Peneliti menginterpretasikan bagaimana subjek memperoleh makna dari lingkungan sekeliling, dan bagaimana makna tersebut memengaruhi perilaku mereka. Penelitian dilakukan dalam latar belakang (setting) yang alamiah (naturalistic) bukan hasil perlakuan (treatment) atau manipulasi variabel yang dilibatkan.

Pada penelitian kualitatif, peneliti memasuki situasi sosial tertentu, melakukan observasi dan wawancara kepada orang-orang yang 
dipandang tahu tentang situasi sosial tertentu. Dengan demikian peneliti menggunakan teknik non probability sampling yaitu purposive sampling. Penentuan sumber data pada orang yang diwawancarai dilakukan secara purposive sampling, yaitu teknik untuk menentukan sampel penelitian dengan beberapa pertimbangan tertentu yang bertujuan agar data yang diperoleh nantinya bisa lebih representatif.

\section{HASIL DAN PEMBAHASAN}

\section{Pemberian Pelatihan Karyawan Untuk Meningkatkan Hasil Kinerja}

Pelatihan sendiri adalah sebagai usaha untuk mengurangi atau menghilangkan terjadinya kesenjangan antara kemampuan karyawan dengan yang dikehendaaki organisasi. Usaha tersebut dilakukan melalui peningkatan kemampuan kerja yang dimiliki karyawan dengan cara menambah pengetahuan dan keterampilan serta mengubah sikap. Selain untuk meningkatkan kinerja, pelatihan merupakan upaya untuk mengembangkan sumber daya manusia, antara lain penambahan wawasan, intelektualitas, karakter, dan mental. Pelatihan karyawan merupakan bentuk investasi perusahaan yang tidak hanya membawa keuntungan yang tinggi, namun juga memiliki dampak positif terhadap kinerja perusahaan. dari penjelasan para informan utama diatas banyak yang mengatakan bahwa pelatihan karyawan merupakan suatu proses untuk meningkatkan kemampuan agar kinerja karyawan lebih baik. Hal tersebut diperkuat dengan pernyataan dari para trigulasi yang dapat disimpulkan bahwa pelatihan sangat penting untuk karyawan dalam rangka peningkatan ketrampilan dan kemampuan untuk kinerja yang lebih baik.

Dari penjelasan tersebut peneliti mengungkapkan bahwa pelatihan karyawan yang dipahami adalah proses pembelajaran atau pendidikan untuk meningkatkan ketrampilan dan kemampuan atau keahlian karyawan agar dapat bekerja lebih baik.

Pelatihan karyawan bagi suatu organisasi atau perusahaan merupakan aktivitas yang penting dilakukan, di mana hal ini akan dapat mempengaruhi tingkat hasil kinerja dan prestasi kerja bagi tenaga kerja itu sendiri dan organisasi atau perusahaan di mana tenaga kerja tersebut bekerja.
Dari jawaban para informan utama banyak yang mengatakan bahwa tujuan pelatihan untuk menambah pengetahuan dan kemampuan karyawan dalam bekerja. Hal tersebut dapat terwujud jika pelatihan dapat terlaksana dengan baik dan mudah dipahami, pelatihan karyawan yang baik tersebut di katakan oleh trigulasi bahwa pelatihan yang baik dan mudah dipahami yaitu dengan memberikan teori secara keseluruhan dan dicontohkan secara langsung, serta pemahaman mengenai sasaran atau tujuan dari pelatihan tersebut.

Dari pernyataan informan utama dan trigulasi , peneliti dapat menyimpulkan bahwa tujuan dari pelatihan karyawan merupakan pengembangan kemampuan, pengetahuan, ketrampilan karyawan agar dapat bekerja lebih baik lagi sehingga dapat tercapai target atau rencana dari perusahaan. Menurut Veithzal Rivai (2015:166) tujuan dari pelatihan adalah meningkatkan kuantitas output, dan meningkatkan kualitas output. Sesuai dari hasil wawancara ternyata sesuai dengan teori tersebut, bahwa tujuan akhir dari pelatihan untuk meningkatkan kualitas dan kuntitas output, dalam hal ini sama dengan meningkatkan hasil kinerja kayawan agar target atau rencana perusahaan dapat tercapai.

Tujuan pelatihan karyawan akan tercapai jika pelatihan karyawan berjalan dengan baik dan dapat dipahami oleh peserta pelatihan, untuk itu instruktur pelatihan yang bertugas dalam penyampaian materi sangat penting dalam hal ini.

\section{Pengembangan Karyawan untuk meningkatkan kemampuan dalam bekerja}

Dari pernyataan informan utama dapat dilihat bahwa peran pengembaganan karyawan di PT Surya Toto Indonesia sudah cukup baik untuk mengembangan pengetahuan, meningkatkan keahlian, juga semangat dalam bekerja guna mencapai tujuan dari perusahaan. Dari jawaban para informan utama banyak yang mengatakan bahwa peran pengembangan karyawan di PT Surya Toto Indonesia cukup baik karena fungsi dari pengembangan itu sendiri dapat meningkatkan kemampuan masing masing dari individu itu sendiri kemudian untuk tercapai dari tujuan perusahaan. Menurut Stewart dan McGoldrick didalam artikel Yustiono (2016) mengatakan pengembangan SDM meliputi berbagai kegiatan dan proses yang diarahkan pada terjadinya 
dampak pembelajaran, baik bagi organisasi maupun bagi individu.

Dari pernyataan informan utama dan triagulasi dapat dikatakan bahwa Pengembangan karyawan sangan berperan sekali untuk karyawan menjadi semakin profesional. Program pendidikan dan pelatihan diadakan secara rutin untuk meningkatkan kualitas dari SDM Perusahaan namun dari segi pelatihan karyawan berharap pelatihan yang diberikan harus sesuai dengan kebutuhan karyawan dan materi yang diberikan sebaikanya dapat di mengerti.

\section{Analisis SWOT ( Strengths, Weaknesses,} Opportunities, Threats )

SWOT adalah identifikasi berbagai faktor secara sistematis untuk merumuskan strategi perusahaan. Berbagai situasi yang dihadapi oleh perusahaan baik internal maupun eksternal harus dapat dijadikan masukan bagi perusahaan guna menentukan rencana strategis dalam menyususn sistem pemasaran yang relatif berdaya guna dan tepat guna. Model yang hingga saat ini banyak digunakan untuk menganalisis situasi bagi perencanaan strategis perusahaan adalah analisis SWOT.

Identifikasi Faktor Internal

\section{Kekuatan ( Strengths )}

Tabel 1. Kekuatan ( Strengths ) Memiliki SDM yang berkualitas

Perusahaan memiliki peralatan atau fasilitas kerja yang lengkap

Merk TOTO sudah memiliki nama dan kualitas yang bagus

Sumber : Data Olahan, 2020

Kelemahan ( Weaknesses )

Tabel 2. Kelemahan ( Weaknesses )

Harga produk yang masih mahal

Peralatan produksi yang masih didatangkan dari luar negeri

Rencana produksi yang belum stabil

Sumber : Data Olahan, 2020

Identifikasi Faktor Eksternal Peluang ( Opportunities )
Tabel 3. Peluang ( Oppurtinities )

Peningkatan pembangunan yang ada saat ini

Beberapa pesaing belum memiliki

beberapa jenis produk baru

Sumber : Data olahan, 2020

Ancaman ( Treats)

Tabel 4. Ancaman ( Treats )

Banyaknya pesaing menjual produk yang lebih murah

Naik turunnya dollar yang masih mempengaruhi penjualan

Sumber : Data Olahan

Kesimpulan dari analisis SWOT PT Surya Toto Indonesia, Tbk terkait dengan kekuatan yang perusahaan miliki yaitu memiliki SDM yang bekualitas sehingga dapat menciptakan produk dengan kualitas yang baik di dalam negeri ataupun luar negeri, dan untuk peluang saat ini banyak pembangunan yang cukup pesat baik tempat tinggal, ataupun gedung gedung besar lainnya. Tetapi ada kelemahan dan ancaman yang di hadapi oleh PT Surya Toto Indonesia, kekurangan yang ada di Perusahaan ini adalah harga yang masih tinggi sehingga tidak semua kalangan bisa membeli produknya. Untuk ancamannya saat ini banyak pesaing baru yang menjual harga lebih rendah serta masih terpengaruh dengan naik turunnya dollar yang mempengaruhi penjualan. Hal ini sesuai dengan penelitian yang dilakukan oleh Syamsudin NoorHasil penelitian menunjukkan bahwa posisi produk berada pada koordinat 3,582 dan 3,551. Koordinat tersebut terletak pada kuadran I yang mendukung strategi pertumbuhan dengan konsentrasi melalui integrasi vertikal. Dari matrik SWOT dapat kita lihat strategi- strategi yang dapat diterapkan untuk meningkatkan pemasaran dan volume penjualan Daihatsu Luxio yaitu meningkatkan hubungan kerjasama dengan pihak bank dan leasing,menjaga dan meningkatkan kualitas pelayanan serta sumber daya perusahaan.

\section{KESIMPULAN DAN SARAN Kesimpulan}

Pelatihan karyawan bagi suatu organisasi atau perusahaan merupakan aktivitas yang penting dilakukan, di mana hal ini akan dapat mempengaruhi tingkat hasil kinerja dan prestasi kerja bagi tenaga kerja itu sendiri dan organisasi atau perusahaan di mana 
tenaga kerja tersebut bekerja. Pelatihan karyawan pada PT Surya Toto Indonesia, Tbk Unit Serpong Bagian Warehouse sudah bisa dikatakan cukup baik, namun pelatihan yang diberikan masih sebatas pelatihan tertulis ini yang terkadang membuat sebagian karyawan kurang menguasai ketika diberikan pelatihan dan juga dalam pelatihan karyawan terdapat beberapa kendala seperti halnya fasilitas penunjang saat pelatihan berlangung.

Pengembangan karyawan merupakan outcomes atau hasil yang berasal dari interaksi antara karier individu pegawai dan proses manajemen karier yang berlaku di perusahaan. Pengembangan Sumber Daya Manusia (SDM) membantu karyawan dalam membangun pribadi mereka dan meningkatkan keahlian berorganisasi, pengetahuan, dan kemampuan bekerja.

\section{Saran}

Perusahaan harus mengevaluasi lebih lanjut terkait dengan pelatihan karyawan yang diadakan, sehingga mengetahui kendala kendala yang ada saat proses pelatihan, seperti salah satunnya dalam hal fasilitas yang digunakan saat proses pelatihan karyawan untuk menunjang proses pelatihan karyawan agar peserta dapat memahami apa yang disampaikan oleh instruktur

Perusahaan dalam meningkatkan kemampuan dan wawasan dalam pengembangan karyawannya peserta sebaiknya menggunakan instruktur pelatihan yang dapat memberikan suasana partisifatif dan inovatif, agar peserta lebih termotivasi dalam mengikuti pelatihan. Walau pelatihan yang diberikan pada bagian warehouse masih seputar pelatihan yang tertulis tetep Diperlukan metode yang lebih beragam juga penerapannya lebih kreatif.

\section{REFERENSI}

Effendy, A., \& Sunarsi, D. 2020. Persepsi Mahasiswa Terhadap Kemampuan Dalam Mendirikan UMKM Dan Efektivitas Promosi Melalui Online Di Kota Tangerang Selatan. Jurnal Ilmiah

MEA (Manajemen, Ekonomi, \& Akuntansi), 4(3), 702- 714. https://doi.org/10.31955/mea.vol4.iss3 .pp702-714

Hasibuan, Malayu S.P. 2010. Manajemen Sumber Daya Manusia. Jakarta : PT. Bumi Aksara.
Herdiansyah, Haris. 2010. Metode Penelitian Kualitatif untuk Ilmu-ilmu Sosial. Jakarta: Salemba Humanika.

Iswara, Marvin Fernaldy. 2016. Analisis Pelatihan Dan Pengembangan Sumber Daya Manusia Di Bank Central Asia Tbk Kantor Cabang Utama Solo Slamet Riyadi. Surabaya : Scholar.

Kasmir. 2016. Manajemen Sumber Daya Manusia (Teori dan Praktik). Jakarta: Rajawali Pers.

Kaswan. 2019. Manajemen Sumber Daya gis: Konsep, Sejarah, Model, Strategi, dan Kontribusi SDM. Yogyakarta: Penerbit Andi.

Khoiri, A., Kahar, M. S., \& Indrawati, R. T. 2018. Ethnoscience Approach in Cooperative Academic Education Programs (COOP). In Journal of Physics: Conference Series (Vol. 1114, No. 1).

Mangkunegara, Anwar Prabu AA. 2011. Manajemen Sumber Daya Manusia. Bandung : PT. Remaja Rosda Karya.

Moeloeng, Lexy J. 2017. Metodologi Penelitian Kualitatif, Edisi Revisi. Bandung : PT Remaja Rosdakarya Offset.

Prasada, D., Sunarsi, D., \& Teriyan, A. 2020. Pengaruh Etos Kerja Dan Kompensasi Terhadap Komitmen Organisasi Pada DHL Logistic Di Jakarta. JENIUS (Jurnal Ilmiah Manajemen Sumber Daya Manusia), 4(1), 51-60.

Purwanto, A., Sunarsi, D., \& Wijoyo, H. 2020. Penerapan Perluasan Arti Perbuatan Melanggar Hukum Dalam Pelaksanaan UU 29 Tahun 2004 (Studi Kasus Putusan No. 625/PDT. G/2014/PN JKT. BRT). TIN: Terapan Informatika Nusantara, 1(2), 99-103.

Rivai, Veithzal dkk. 2010. Manajemen Sumber Daya Manusia Untuk Perusahaan Dari Teori Ke Praktik. Jakarta : PT. Raja Grafindo Persada.

Sinambela, LP. 2018. Manajemen Sumber Daya Manusia. Jakarta: Bumi Aksara.

Sondang P Siagian, 2015, Manajemen Sumber Daya Manusia, Jakarta. Bumi Aksara. Sugiyono. 2016. Metode Penelitian Kualitatif, Kuantitatif, dan $R \& D$, Cetakan ke 23. Bandung : Alfabeta. 
Sunarsi, D. 2018. Buku Ajar: Seminar Perencanaan Sumber Daya Manusia. Tangerang Selatan: Asmoro Mediatama

Sunarsi, D. 2018. Buku Ajar: Seminar Perencanaan Sumber Daya Manusia. Tangerang Selatan: Asmoro Mediatama

Sunarsi, D. 2018. Pengembangan Sumber Daya Manusia Strategik \& Karakterisrik Sistem Pendukungnya : Sebuah Tinjauan. Jurnal Ilmiah MEA (Manajemen, Ekonomi, \& Akuntansi), 2(3), 178 - 194.

Sunarsi, D. 2018. Pengembangan Sumber Daya Manusia Strategik \& Karakterisrik Sistem Pendukungnya : Sebuah Tinjauan. Jurnal Ilmiah MEA (Manajemen, Ekonomi, \& Akuntansi), 2(3), $\quad 178 \quad$ - 194. https://doi.org/10.31955/mea.vol2.iss3 .pp178 - 194

Sunarsi, D., Wijoyo, H., Prasada, D., \& Andi, D. 2020. Pengaruh Lingkungan Kerja Terhadap Kinerja Karyawan Pada PT. Mentari Persada Di Jakarta. In Seminar Nasional Manajemen, Ekonomi, Akuntansi (Vol. 5, No. 1, pp. 117-123).

Sunarsi, D., Winata, H., Gunartin, G., \& Paeno, P. 2020. Analisis Gaya Kepemimpinan Kepala Desa Dalam Pengembangan Desa Cidokom Gunung Sindur Kabupaten Bogor. Jurnal Ekonomi Efektif, 2(3).

Sutrisno, Edy. 2014. Manajemen Sumber Daya Manusia, Cetakan ke 10. Jakarta. Kencana.

Wibowo. 2016. Manajemen Kerja, Edisi V, Cetakan ke 10. Jakarta : PT Rajagrafindo Persada. 